\title{
Audiovisual cultural artifacts of protest in the Basque Country
}

\section{ABSTRACI}

In this article we propose the emergence of a new kind of visual protest and alternative communication called the Audiovisual Cultural Artifact of Protest (ACAP). These will be studied in the context of the Basque Country, which currently combines structural and conjunctural characteristics that make it an outstanding laboratory for the study of these artifacts. A theoretical analysis of the complex relationships between power, communication and resistance will be carried out, and a reading is proposed that deals with the different planes on which these resistances and disputes are expressed. Based on this analysis, four kinds of audiovisual artifacts produced in the Basque Country are studied. For the empirical analysis, the methodological reflections of visual sociology are taken into consideration. The results provide an overview of these Audiovisual Cultural Artifacts of Protest and the theoretical discussion confirms the emergence of these new forms of visual protest, indicating the existence of a broad-based dynamic in which their proliferation and diversification is occurring. The analysis of the case of the Basque Country allows these tactical and communicative innovations to be contextualised and a discussion to take place about the importance of that context, the discourse's construction and the possible trend towards spectacularisation of the resistances.

Keywords: ACAP, Basque Country, protest, visuality, media, social movements

\section{ARKAITZ LETAMENDIA, ION A. DEL AMO and JASON DIAUX University of the Basque Country (UPV/EHU)}

7 HE APPEARANCE of new communication channels is a significant influence on the structure of power in societies. Firstly, they bring the emergence of new power centres, with a resulting increase in tension within the dominant structure. Furthermore, they sometimes undermine the hierarchical control of social knowledge, bypassing mediating agencies 
and distributing alternative information (Curran, 2005). Currently, together with the spread of Information and Communication Technology (ICT), while new power centres are being configured structurally, there are also emerging new communicative expressions that try to undermine hierarchical control and set themselves up as tools of resistance. It is in this last sphere where we locate the phenomenon analysed in this article: the Audiovisual Cultural Artifacts of Protest (ACAPs). This article will look at the characteristics and emergence of ACAPs as tools for contemporary political protest for the case of the Basque Country.

ACAP refers to all those audiovisual tools and productions, recorded and uploaded onto the Internet, by which groups of people intend political protest or demands. We start from the idea that all cultural artifacts allude, by definition, to 'anything created by humans which gives information about the culture of its creator and users' ${ }^{1}$. The study of ACAPs emphasises the audiovisual nature of these artifacts, given that these are videos that produce different combinations of visuality, musicality and theatricality. Furthermore, this study will look at not only the cultural context in which they have arisen, but also the political context that these artifacts attempt to influence, creating resistances and modifications to existing power structures. As we will see, lip $d u b s$, flash mobs, symbolic visual actions and recorded protest performances of different kinds are some of the examples that constitute ACAPs and which will be analysed in this article, focussing on the Basque case.

\section{Key points in the debate on Communicative Dominance and Resistances}

To study the emergence of ACAPs, some of the major points in the theoretical debate regarding communications, upon which this article's proposal is based, will first be looked at. The appearance of mass media was to trigger a long academic, political and social debate about their role ${ }^{2}$. The discussion has often swung between two opposing positions: the agony of dominance, and a technological optimism - and determinism. So a first overall perspective, embodied in the work of Adorno and Horkheimer (1994), would cover dominance: the culture industry is both the medium - the mechanised techniques of transmission and reproduction - and the message.

A second perspective, from the Latin American sphere and put forward by Martín-Barbero (1993) and García Canclini (2001, 2002), would invert the agonising position of Adorno. Using as a foundation the reference of Walter 
Benjamin and the Gramscian concept of hegemony (Gramsci, 2009), this position would take the opposite point of view. According to these authors, all is not dominance, since there are other logics in which the message is not so important, given that it is reinterpreted through the prism of popular culture and experience. This experience, which is memory and practice, is the mechanism with which the popular classes unconsciously and effectively confront the massive (Martín-Barbero, 1993).

Another and third view, similar to the last one but which concentrates more on communicative articulations (and contradictions), was developed based on the work of Raymond Williams by researchers connected to the Centre for Contemporary Cultural Studies (CCCS) in Birmingham: Hall, Cohen, Clarke, Willis and Hebdige. Also supported by the Gramscian concept of hegemony, they attempt to understand the structural localisation of working-class youth and the cultural and political meaning of its group cultural practices (and their potential for resistance) through the lenses of spectacular subcultures. A concept that is central to this perspective is that of the 'double articulation' (Hall \& Jefferson, 1998), between culture of working class or ethnic origin and, on the other hand, the dominant culture, especially present in the media.

The CCCS research would give rise to a vigorous debate which would question the importance of the structural conditions, especially class, the role of the media and the political meaning of cultural practices. Griffin (2011) particularly defended a legacy of the Birmingham project, something that this article will use to explain the emergence of ACAPs: the desire to develop symptomatic reading within the frame of a conjunctural analysis in relation to social, economic and political conditions.

So mass media devices are structurally linked to the reconstruction of the hegemony that is built around culture; and from a time, the 1920s, these devices would play an important role (Martín-Barbero, 1993). This view allows the relationships between power (Bourdieu, 2002; Gurevitch, Bennett, Curran, \& Woolacott, 1982) and resistance to be contextualised and read in a richer and more complex way.

\section{Communicating the Resistance}

This article proposes that resistances may act on various planes:

1. In the most purely symbolic and ideological sense, resisting hegemonic, totalising categorisations, escaping from them and questioning them. This resistance involves the work of constantly fleeing from hegemonic

226 PACIFIC JOURNALISM REVIEW 20(2) 2014 
narratives that will try to hegemonise or stigmatise it (Laclau, 2005; Laclau \& Mouffe, 2001; Zizek, 1989).

2. Secondly, communication is also community life and it is there where power attempts to constitute its determinations. Thus a dispute arises in which power unfolds a series of mechanisms aimed at the production of subjectivity, by means of concealment and remembering only the present, symbolic of the destruction of the community processes of social communication (Pascual, 2010). Resistances would be structured in the maintenance or construction, whether symbolic or material, of those community processes of social communication that relativise and modulate the influence of mass media (MartínBarbero, 1993). A particular dimension in which this resistance materialises is related to street life and protest (Delgado, 1999, 2011)

3. Thirdly, explicit practices meet on the symbolic and communicative plane; from the symbolic distortion of the Situationists' détournement to the importance of the spectacular/communicative in movements like Greenpeace, or guerrilla communication actions.

Slavoj Zizek warns about the depoliticisation of the economic sphere ('It's the political economy, stupid') which could involve an excessive emphasis on culture by some movements:

The price of the depoliticisation of the economy is that the very sphere of politics, in a certain way, becomes depoliticised: the true political struggle becomes a cultural battle for the recognition of marginal identities and for the tolerance of differences (Zizek, 2009, p. 59).

In another formulation, Boltanski and Chiapello (2002) seem also to point in the same direction when they warn of and describe the problems and related neutralisations of separating historical forms of critiquing capitalism, social critique and artistic critique.

Furthermore, in these resistances there are tactical innovations and strategic action, but also more. Eyerman and Jamison (1998) highlight the idea that the construction of social representations does not just take place in the mass media but also, as has been pointed out, in community processes of social communication and particularly in the heart of the social movements. This construction has both a dimension that is outward facing, of contra-information, and one that is inward facing, of experience and construction of identity and 
of self-expression. Cultural traditions mobilise and reformulate themselves as part of social movements, structuring the different forms of resistance and their relationship with hegemony by offering visions and models of alternative forms of meaning and identity that can be chosen consciously.

\title{
What's new in the media?
}

With the development of ICT, authors such as Jenkins (2008) point to the convergence of the mass media, old and new, popular and corporate, and the emergence of a participative culture ${ }^{3}$. Applied to social mobilisation, Castells (2012) describes the transformation of mass communication into mass selfcommunication, in which subjects can build their own communication networks, amplifying the social movements' possibilities of autonomous action. In this regard, other research also indicates that, on the internet, user-generated content (UGC), based on characteristics such as expressiveness, performativeness and collaboration, promotes political participation (Ostman, 2012). So Shifman (2012) states that YouTube can be considered an emblem of participative culture, in that it connects with economic as well as social and cultural logics of participation.

However, Castells also warns of aspects such as the growing concentration of the global networks of multimedia companies ${ }^{4}$, as well as the digital divide in terms of access and education, which 'tend to reproduce and amplify the class, ethnic, race, age and gender structures of social domination between countries and within countries' (Castells, 2009, p. 57). He also points out that:

\begin{abstract}
(...) the cultural dimension of the process of multi-layered transformation of communication can be grasped at the intersection of two pairs of contradictory (but not incompatible) trends: the parallel development of a global culture and multiple identity cultures; and the simultaneous rise of individualism and communalism as two opposing, yet equally powerful, cultural patterns that characterize our world (...). The abiliity or inability to generate protocols of communication between these contradictory cultural frames defines the possibility of communication or miscommunication between the subjects of diverse communication processes (Castells, 2009, p. 56).
\end{abstract}

Indeed, with ACAPs we are dealing with a global phenomenon. However, at the same time, local contexts like the Basque Country are especially prolific, 
given that they are sources of major mobilising networks and cultures, as well as recent political changes. Castells (2009) has already stated that national, regional, local or non-state identities continue to be a principle of identification as resistance identities, in the cases in which they confront the challenges of globalisation or of dominant nation-states.

\section{Tuning in to the Basque Country}

The last 35 years in the Basque Country have seen many and varied resistances and disputes around definitions of reality. The dispute for hegemony between the Basque national and Spanish national narratives has overdetermined the social scene through a politics loaded with emotion.

The decade of the 1980s saw the emergence of what Jakue Pascual (2010) has called the Youth Resistance Movement, organised around punk and Basque Radical Rock, which undertook a spatial redefinition ('the street', certain bars, festive spaces, a wave of squatting to create gaztetxes - 'occupied youth centres') and was manifested in a constellation of small record labels and expressive communication channels (fanzines, magazines, free radio stations, music, concerts, style...). This movement involved the development of a culture known as Basque Radical Culture, in the words of Luis Sáenz de Viguera:

(...) a social, political and cultural phenomenon that disrupts the categories of political subjectivity established by the framework of political-institutional narratives that make up the social space. From its margins, although always pointing towards an impossible outside, radical culture would be a protean phenomenon, difficult to classify in that it would arise precisely as an escape from the site of identification and structuring of the social (Sáenz de Viguera, 2007, p. 4).

In this way, "the distance between democratic (media) discourses and the brutal realities of crisis, unemployment and continuing repression now justified by the system, by the alliance between the new democratic parties and the old forces of order' (Sáenz de Viguera, 2007, p. 167) were expressed.

This radical culture maintained a special interaction with a Basquespeaking culture which, because of its subordinate character with regard to the dominant (Spanish-speaking) one, is also structured as a popular culture (Amezaga, 1995). This relationship was reflected in the growing role of the Basque language (Amezaga, 1995; Urla, 2001) or in the -contentious- attempts 
to enter the mobilising (contra)hegemonic narratives of the Basque nationalist left (Lahusen, 1993; Pascual, 2010; Sáenz de Viguera, 2007).

However, in the Spanish state media and the hegemonic narrative the link between 'Basque' and 'radical', overdetermined by politics and the traumatic reality of violence, has been subjected to strong processes of representation and stereotypification. These processes homogenise all the Basque resistances, inserting them into criminalising narratives that unify diverse expressions: youth movements, radical culture, music, political movements and violent acts. These criminalising processes are materially expressed in the doctrine of 'all is ETA' ${ }^{5}$ applied by the Spanish legal system, which has meant measures such as the closure of Basque newspapers and radio stations and the boycotting or banning of concerts (Sáenz de Viguera, 2007).

At the current time we are experiencing major changes in the Basque socio-political context. Firstly, a shift in politics, marked by the definitive ceasefire in 2011 of the Basque armed organisation ETA. So sectors of the Basque pro-independence left are now more openly engaging in strategies of disputing the political hegemony. Furthermore, the economic crisis and its consequences are producing a strong questioning of hegemonic narratives at the level of the Spanish state.

In this context, a proliferation of audiovisual cultural artifacts, ACAPs, is occurring in the Basque Country, by means of which some groups seem to be trying to dissolve stereotypes, disputing hegemonic narratives.

\section{Empirical analysis methodology and approach}

In order to carry out this analysis, we start from the interpretive paradigm (Lindlof, 1995): using the study of videos selected from YouTube, we interpret visual texts through constant reference to the social context and to the power relationships produced in this context. As has been stated, this is based on an interpretive current and it takes into consideration deep political critique, focussing on culturally situated communication and looking at the political meaning (of resistance or pro-social order) that exists in all texts and cultural practices. It is crucial in this perspective to talk about hegemony. If the videos -visual texts- that are going to be analysed are considered as cultural artifacts, then this (theoretical and empirical) proposal is the method by which the analysis is to be carried out.

These are videos posted on YouTube, and therefore with a potential for 
mass dissemination, that have been created recently; none of them was made before 2011. They are studied following the qualitative analysis model proposed by Lindlof (1995). According to this author, there are four stages for analysing data texts - in this case visual ones - and these four form part of an inductive process. The four stages are: the codification process (first-level or descriptive codes and second-level, conceptual or cultural codes); the reduction process; the explanation process; and finally the theory construction process, which will be referred to in this study's conclusions.

\section{Kinds of ACAP analysed}

For the analysis we have selected four kinds of audiovisual artifacts that are presented below in chronological order. They have been selected because of the response they received and their representativeness of different themes and forms of demand and protest:

Basque protest flash mob: in contrast to typical flash mob examples, in the Basque case we see a previously organised popular dance with the aim of making a demand or raising awareness. In this case, the video refers to an ecological conflict around the project of constructing a rubbish incineration plant in the Basque province of Gipuzkoa.

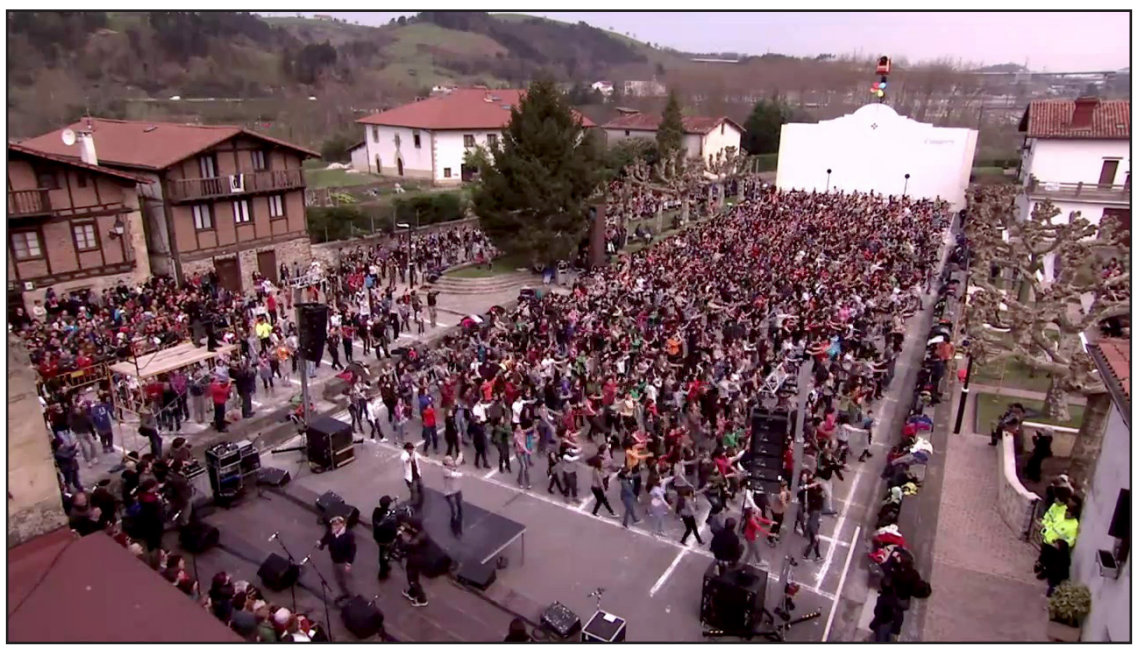

Dancing for clean air (2011): www.youtube.com/watch?v=BpJBhZCS7YE (Retrieved on 8 January, 2014) 
Protest lip dub: these are videos of a group performance in which a political demand is made; they use a song as a unifying thread and are recorded using a single tracking shot. There are many examples of lip dubs made in the Basque Country, but this has been chosen for its contemporary relevance, quality and level of popular participation. This ACAP is a call to attend a demonstration in favour of the rights of the Basque political prisoners.

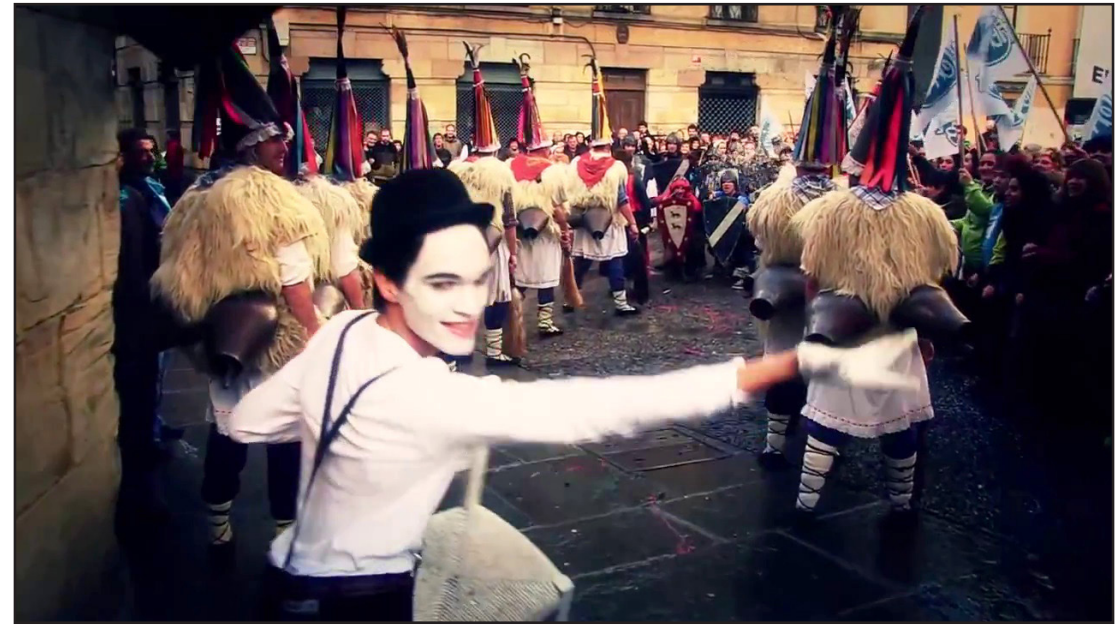

\#U12Bilbora: MobiLIPDUBzioa Durangon (2012):

www.youtube.com watch?v=mREEbtkzh2o (Retrieved on 8 January, 2014)

Simulated video: Unlike the others, this video could be considered an example of guerrilla communication rather than popular participation. It is a parody, simulating the kidnapping of an artwork ('the Getxo Merman') to protest against a speculative urban development plan.

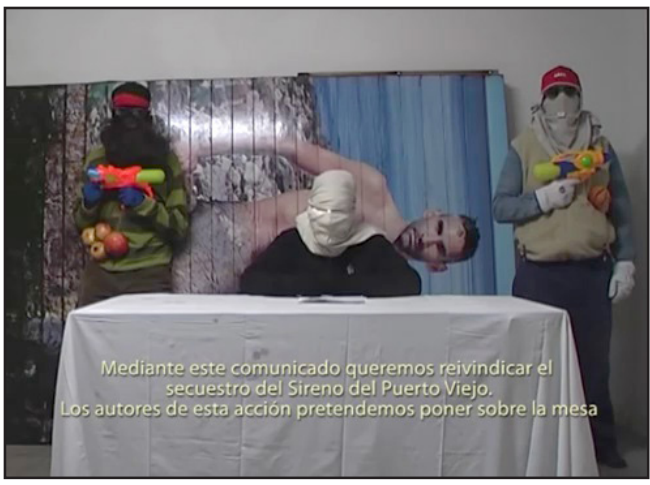

¿Dónde está el sireno? (2013): www.youtube.com/watch?v=uZSjHC5_Zv4 (Retrieved on 8 January, 2014) 
Spectacular demonstration: An action that incorporates visual and performative elements to protest against the Spanish state's penitentiary policy. The video is also a call to attend a demonstration convoked for the 11th of January, 2014, in Bilbao, under the motto 'Give peace a chance in the Basque Country. REPATRIATE ALL BASQUE PRISONERS', at which it was also planned to reproduce these visual elements on a large scale. ${ }^{6}$

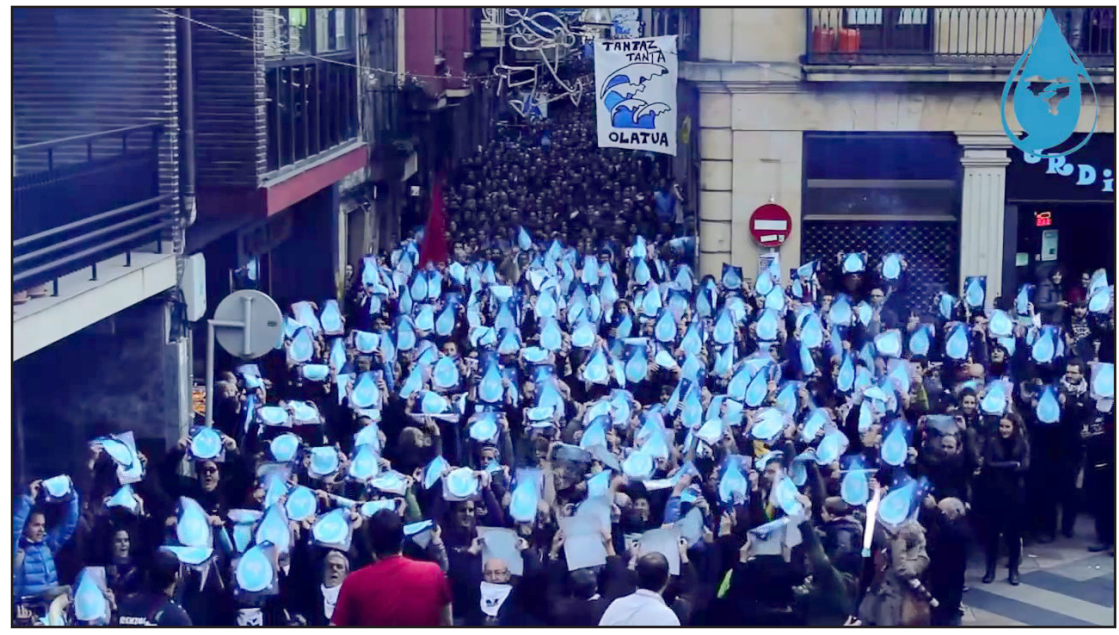

Tantaz Tanta Olatua (2013):www.youtube.com/watch?v=wjLQH-kszl4 (Retrieved on 8 January, 2014)

\section{Results obtained}

Below is a presentation of the results obtained after carrying out the first two stages referred to in the methodology proposed by Lindlof (1995): those of codification and later reduction of the most important characteristics of the ACAPs analysed.

\section{First-order or descriptive codes}

\section{General characteristics}

- Visual impact, images, colour: viewers witness a continuous display of explicit and direct images, given a striking colouring through which participants are seen.

- Instantaneousness: instant dissemination of the information, once it is uploaded onto the internet. 
- Direct expressiveness: emotional expressiveness, striking visual character and explicit message.

- Positivity: fun, cheerfulness and an optimistic tone.

- Dynamism of the images: choreographic movement, changing planes and the travelling movement of the camera shot (with the exception of the 'Getxo Merman' video which simulates a kidnapping recorded in a static shot).

- Carefully made, quality images: well-prepared script, rehearsing, direction, editing and transmission.

Specific characteristics of the Basque ACAPS

- Profusion of symbols: this is clear in the Basque case. There are a large number of visual symbols, in some cases representing different demands.

- Basque soundtrack: in most cases a convergence between the musical and the linguistic is produced by means of songs in the Basque language; in others this is achieved through textual narration.

- Characteristic Basque elements: an outstanding feature is the presence of dress, musical instruments and figures from Basque popular tradition, folklore and mythology.

- Theatricality, costumes, dance: this is a feature that is strongly related to a dynamic, playful spirit. A profusion of costumes appears, along with highly theatrical performances and both contemporary and traditional dance.

- Individual-group focus: with the exception of the distinctive aesthetic of the 'Getxo Merman' video, the images combine mainly foreground shots with group shots, re-enacting a kind of 'changeover' among the participants. Focus switches between the individual and the community.

\section{Second order or interpretive codes}

- Emotional appeal: there is a stimulation of the emotions and feelings of those participating in the event by means of the aesthetic combination of music, symbols and colourful images. This involves an appeal, searching for an emotional connection with the viewer, beyond the message's rational element.

- Representation and representativeness: a representation of different 
social movements and struggles is produced. In the specific case of the lip $d u b$, different demands are represented, including national liberation, feminist, squatting, trade union, euskaltzale (pro-Basque language), youth, ecological and internationalist rights. Through the ACAPs, the representativeness of the demands is sought, in most cases showing mass and popular participation in the videos. The visual symbolism also appeals to a representativeness that goes beyond that explicitly represented in the videos' images.

- Tradition versus modernity?: the ACAPs are an exercise in adapting to new technologies. In them there are references and humorous nods to traditional, historical and ethnic Basque elements. Memories of tradition merge, become updated and are communicated in these videos.

- A spirit of group action: an exercise in popular action that symbolises and materialises the idea of group strength is staged.

- Alternative viewpoint: in the ACAPs different social movements launch their messages and demands. In them, alternative views and models of the world are staged.

- Cultural connection: there is a clear bid to show identity by representing Basqueness, using folk, historical or artistic elements.

\section{Conclusions and proposals for discussion}

We have attempted to underline the growing role that Audiovisual Cultural Artifacts of Protest (ACAP) have in the sphere of the communicative dispute over hegemony, as well as their relationship to the socio-political context in which they arise. Below, ideas considered to be crucial in this regard are examined. The conclusions presented here correspond to the stages of theoretical explanation and construction proposed by Lindlof (1995).

\section{Media resistance: Innovation and context}

ACAPs are configured as a new form of protest, a tactical innovation (McAdam, 1983; Morris, 2003). As stated by Castells (2009, 2012), mass selfcommunication is a tool that can be useful and effective for the social movements. In the ACAPs studied here, the global dissemination of videos on the web and the non-existence on the Internet of certain filters previously imposed by major mass media organisations allow the opening of new communication channels to express other viewpoints on the social reality. 
However, it is not the intention of this article to propose that this communicative dispute phenomenon is radically new. In fact, the experiences of alternative communication for the Basque case, which were and still are especially rich, have been looked at. Fanzines, posters, banners, murals and especially free radio stations, as well as Basque rock and the radical culture organised around it, have been lively examples of alternative communication, allowing people to organise their own symbolic and communicative spaces. It could even be said that in the Basque context, mass self-communication already existed, or at least the intention was there. ICT enables the message to have a more massive, more global reach.

The prior existence of alternative communicative spaces and their mobilisation networks has allowed the fast and prolific emergence of ACAPs, made possible by the resources of ICT, to be understood. This process is favoured by the change in the Basque political context, marked by the end of ETA's armed activity. The notable proliferation of the ACAPs, which require high levels of organisation, is especially significant. To explain it, it is necessary to bear in mind those elements: the sum of the communicative dispute tradition, mobilisation networks and the new political context.

\section{The construction of discourse}

The ACAPs and their contrahegemonic representation by means of videos visible to the whole world, emerge in this context. They display theatrical, positive forms, with a unifying intention and focussed towards communicative dispute, but also with a strongly self-expressive component (Eyerman \& Jamison, 1998) and where the emotional (Goodwin, Jasper \& Polleta, 2001) plays a central role.

With regard to the new forms of communication, Castells (2009) underlines the capacity to articulate two pairs of contrasting cultural frameworks: the global and local identity, and the individual and the community. We have seen in the analysis of the ACAPs that this articulation seems to be particularly well achieved. Firstly, that careful expression of the appearance of specific people within a community framework has been pointed out, which overcomes the dichotomy between anonymous mass and isolated individualism. Secondly, matters of identity are clearly present in the protests, in the music and in the references to traditional -and modern- Basque elements. The global is present in two ways: on one hand in a use of the communication networks and their 
claim to global dissemination; and in a staging and iconography of different Basque struggles that connect with universal demands and values, such as human rights and ecologism.

\section{The spectacle of the struggle?}

Martín-Barbero (1993) points out how the expansion of mass culture is a democratisation of culture, but also a certain banalisation of it; it is worth making the parallel with regard to the democratisation of the media involved in the ACAPs. The turn towards communication, especially audiovisual communication, involves an intrinsic contradiction: the critique of the 'spectacularisation' of life is done using spectacle. The risk of emptiness and banalisation is present, as is the risk of confinement to media battles. In the videos analysed this does not seem to happen: they require and also seek broadbased popular participative mobilisation, in the street, and in many cases extend connections to other mobilisations.

It is worth indicating another contradiction: merely identity-based protests and battles in exclusively cultural spaces can depoliticise the political and fit into the post-political (Zizek, 2009). The ACAPs analysed also seem to escape from this objection. The specific demands of each of these struggles stage an alternative that is both antagonistic to the existing and with intended contrahegemonic effect.

In short, the ACAPs do not seem to replace the struggles, only give them greater visibility. Whether this continues to be the case will depend on whether, beyond the audiovisual, these socio-cultural and political conditions, which have fed these symbolic, communicative and mobilisation spaces, are maintained.

\section{Mutating ACAPs}

This article proposes the emergence of ACAPs as a new form of protest and alternative communication. It defends the existence of a broad-based dynamic, the proliferation and diversification of ACAPs, which are experiencing innovations and are mutating in their forms within the framework of the general characterisation described. The theoretical analysis allows ACAPs to be situated as part of a global phenomenon, with the Basque Country constituting an outstanding laboratory for their creation, as well as research into them, because of the special structural and conjunctural characteristics 
of the present historical moment. Therefore, the ACAPs, whatever their specific form, seem to be among us in order to resist.

\section{Notes}

1. Retrieved on 8 January 2014, from http://en.wikipedia.org/wiki/Cultural artifact 2. Authors such as Curran (2005) deny that mass communication is an exclusively modern phenomenon. According to this author, the clearest and most successful example of pre-industrial mass media was the Church, controlled by the papacy, with a whole series of non-verbal (statues, buildings, rituals) and verbal (sermons, books) communication techniques based on religious magic, by which it established its mastery over institutional processes of ideological production (Curran, 2005).

3. Although Jenkins (2008) indicates that not all participants are created equal and they do not all have the same resources.

4. Castells says that 'the revolution in communication technology and the new cultures of autonomous communication are processed and shaped (although not determined) by organisations and institutions that are largely influenced by business strategies of profit-making and market expansion' (Castells, 2009 p. 71).

5. ETA (Euskadi ta Askatasuna) is an armed Basque national liberation organisation created in 1959, and which in 2011 declared the definitive termination of its actions. 6. However, the demonstration was banned by the Spanish courts, causing a massive protest mobilisation on 11 January 2014 in the city of Bilbao convoked by the main Basque parties and trade unions.

\section{References}

Adorno, T. W., \& Horkheimer, M. (1994). Dialéctica de la ilustración. Madrid: Trotta. Amezaga, J. (1995). Herri kultura: Euskal kultura eta kultura popularrak. Leioa: UPV-EHU.

Boltanski, L., \& Chiapello, E. (2002). El nuevo espíritu del capitalismo. Madrid: Akal. Bourdieu, P. (2002). Cultural power. In L. Spillman (Ed.), Cultural sociology (pp. 69-76). Oxford: Blackwell Publishers.

Castells, M. (2009). Communication power. New York: Oxford University Press.

Castells, M. (2012). Autocomunicación de masas y movimientos sociales en la era de Internet. Anuari del conflicte social 2011, 11-19.

Curran, J. (2005). Medios de comunicación y poder. Barcelona: Hacer.

Delgado, M. (1999). El animal público. Hacia una antropología de los espacios urbanos. Barcelona: Anagrama.

Delgado, M. (2011). El espacio público como ideología. Madrid: La Catarata.

Eyerman, R., \& Jamison, A. (1998). Music and social movements. Cambridge: Cambridge University Press. 
García Canclini, N. (2001). Culturas híbridas. Estrategias para entrar y salir de la modernidad. Barcelona: Paidós.

García Canclini, N. (2002). Culturas populares en el capitalismo. México: Grijalbo.

Goodwin, J., Jasper, J., \& Polletta, F. (2001). Introduction: Why emotions matter. In J. Goodwin, J. Jasper and F. Polletta (Eds.), Passionate politics. Emotions and social movements. (pp. 1-24). Chicago: The University of Chicago Press.

Gramsci, A. (2009). La política y el estado moderno. Madrid: Público.

Griffin, C. E. (2011). The trouble with class: researching youth, class and culture beyond the 'Birmingham School'. Journal of Youth Studies 14(3), 245-259.

Gurevitch, M.; Bennett, T.; Curran, J., \& Woollacott, J. (1982). Culture, society and the media. London: Methuen.

Hall, S., \& Jefferson, T. (Eds) (1998). Resistance through rituals: Youth subcultures in post-war Britain. London \& New York: Routledge.

Jenkins, H. (2008). La cultura de la convergencia de los medios de comunicación. Barcelona: Paidós.

Laclau, E. (2005). La razón populista. Buenos Aires: FCE.

Laclau, E., \& Mouffe, C. (2001). Hegemony and socialist strategy: Towards a radical democratic politics. London: Verso.

Lahusen, C. (1993). The aesthetic of radicalism: the relationship between punk and the patriotic nationalist movement of the Basque country. Popular Music, 12(3), 263-280.

Lindlof, T. R. (1995). Qualitative communication research methods. Thousand Oaks, CA: SAGE Publications.

Martín-Barbero, J. (1993). De los medios a las mediaciones. Comunicación, cultura y hegemonía. México: GG Mass media.

Mc Adam, D. (1983). Tactical innovation and the pace of insurgency. American Sociological Review, 48(6), 735-754.

Morris, A. (2003). Tactical innovation in the civil rights movement. In J. Goodwin, and J. Jasper (Eds), The social movements reader. Cases and concepts (pp. 229233). Malden, MA: Blackwell Publishing.

Ostman, J. (2012). Information, expression, participation: How involvement in usergenerated content relates to democratic engagement among young people. New Media \& Society, 14(6), 1004-1021.

Pascual, J. (2010). Movimiento de resistencia juvenil en los años ochenta en Euskal Herria. Unpublished doctoral dissertation. Universidad del País Vasco / Euskal Herriko Unibertsitatea (UPV-EHU), Basque Country.

Sáenz de Viguera, L. (2007). Dena ongi dabil! ;Todo va dabuten! Tensión y heterogeneidad de la cultura radical vasca en el límite del estado democrático (1978-...). Doctoral dissertation. Retrieved fron Duke Space. (http://dukespace.lib.duke.edu/ dspace/handle/10161/390)

Shifman, L. (2012). An anatomy of a YouTube meme. New Media \& Society, 14(2), 187-203.

PACIFIC JOURNALISM REVIEW 20 (2) 2014239 
Urla, J. (2001). We are all Malcolm X!: Negu Gorriak, hip-hop and the Basque political imaginary. In T. Mitchell (Ed.), Global noise: Rap and hip-hop outside the USA (pp. 171-193). Middletown, CT: Wesleyan University Press.

Zizek, S. (1989). The sublime object of ideology. London: Verso.

Zizek, S. (2009). En defensa de la intolerancia. Madrid, Sequitur.

Arkaitz Letamendia, Ion Andoni Del Amo and Jason Diaux are doctoral candidates at the University of the Basque Country (UPV/EHU), Northern Spain. Letamendia and Diaux are in the Department of Sociology II and Del Amo is in the Department of Audiovisual Communication and Publicity and member of NOR Research Group. An earlier version of this article was presented at the Protest Movements, Free Speech and the Media Conference at the Goldsmiths Centre for the Study of Global Media and Democracy, University of Westminster, London, on 12-13 June 2013. arkaitz.letamendia@ehu.es

\section{A[प] COMMUNICATIONS}

\section{POSTGRADUATEJOURNALISM}

Bachelor of CommunicationStudies(Hons) offers students either an applied or an academic pathway incommunication studies. Papers and strands include Asia-Pacificjournalism, digital media, investigative journalism, public relations and screen writing.

Master of Communications Studies(MCS) is a postgraduateresearch degrèe offering practical options. Doctorate in Communication Studies (PhD) is a thesis-based research degreegranted on the basis of 4 original and substantive contribution to knowledge. TheFaculty of:Designand Ereative industries encourages and supports innovative interdisciplinary research. The School pf Communication Studies has supervising staff whose research interests cover a range of areas encompassing media, politics' and ownership, journalism, human communication, new media and development, discourse analysis and popular culture.

Email: commstudies国aut.ac.nz | Web: www.commstudies.aut.ac.nz

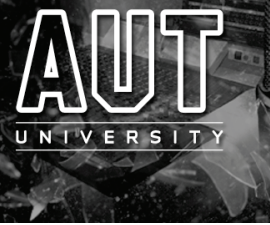

240 PACIFIC JOURNALISM REVIEW 20(2) 2014 